$\begin{array}{ll}\text { Abstracta Iranica } & \begin{array}{l}\text { Abstracta Iranica } \\ \text { Revue bibliographique pour le domaine irano-aryen }\end{array} \\ & \text { Volume } \mathbf{4 2 - 4 3} \text { | } \mathbf{2 0 2 1} \\ & \text { Comptes rendus des publications de 2019-2020 }\end{array}$

\title{
Aaron Michael Butts, Simcha Gross (eds.). Jews and Syriac Christians: Intersections across the first Millennium
}

Florence Jullien

\section{(2) OpenEdition \\ Journals}

Édition électronique

URL : https://journals.openedition.org/abstractairanica/54204

DOI : 10.4000/abstractairanica.54204

ISSN : 1961-960X

Éditeur :

CNRS (UMR 7528 Mondes iraniens et indiens), Éditions de l'IFRI

Référence électronique

Florence Jullien, « Aaron Michael Butts, Simcha Gross (eds.). Jews and Syriac Christians: Intersections across the first Millennium », Abstracta Iranica [En ligne], Volume 42-43 | 2021, document 33, mis en ligne le 30 décembre 2021, consulté le 25 décembre 2022. URL : http://journals.openedition.org/ abstractairanica/54204; DOI : https://doi.org/10.4000/abstractairanica.54204

Ce document a été généré automatiquement le 25 décembre 2022.

Tous droits réservés 


\section{Aaron Michael Butts, Simcha Gross (eds.). Jews and Syriac Christians: Intersections across the first Millennium}

Florence Jullien

\section{RÉFÉRENCE}

Aaron Michael Butts, Simcha Gross (eds.). Jews and Syriac Christians: Intersections across the first Millennium. Tübingen : Mohr Siebeck, 2020, XII-350 p. ISBN : 978-3-16-159134-1. (Texts and Studies in Ancient Judaism 180)

1 Ce volume collectif réunit seize contributions sur les échanges entre communautés juives et chrétiennes syriaques: thématiques ou motifs littéraires partagés, lieux de contacts, rencontres interpersonnelles, sujets littéraires ou exégétiques communs, élargissement des frontières communautaires, interactions sociales ou économiques réunis sous le terme d' " intersections ». Dans le contexte culturel iranien, les échanges intercommunautaires entre juifs et chrétiens se sont beaucoup exprimés au IV siècle, et des influences réciproques ont pu s'opérer, même si les similitudes thématiques et herméneutiques participent souvent d'un fond commun, comme l'avait relevé E. Lizorkin (Aphrahat's Demonstrations. A Conversation with the Jews of Mesopotamia, [CSCO 642, Subsidia 129], Louvain, 2012 ; cf. N. Koltun-Fromm, "Jewish-Christian Conversation in Fourth-Century Persian Mesopotamia", Journal of Jewish Studies 47/1 [1996], p. 47-63). Les éditeurs du volume le montrent bien, soulignant qu'il s'agit le plus souvent d'une série de tendances culturelles convergentes. Les contributions élargissent le champ de prospection sur un millénaire. L'ensemble ouvre à des questionnements transdisciplinaires, transversaux aux domaines des études juives et des études chrétiennes syriaques. 
M. Bar-Asher Siegal, "Syriac Monastic Motifs in the Babylonian Talmud: The Heruta Story Reconsidered (b. Qiddushin 81b)” (p. 27-46). L’A. résume les grandes lignes de son ouvrage paru en 2013: Early Christian Monastic Literature and the Babylonian Talmud. Cambridge : Cambridge University Press (Cf. le compte rendu dans Abstracta iranica, 34-35-36/2011-2013).

B. Belinitzky, Y. Paz, "Bound and Banned: Aphrahat and Excommunication in the Sasanian Empire" (p. 67-88);

S. J. D. Cohen, "Jewish Observance of the Sabbath in Bardaișan's Book of the Laws of Countries" (p. 89-102);

6 S. H. Griffith, "Jewish Christians and the Qur' ân: The Transit of Religious Lore in Late Antique Arabia" (p. 103-120);

7 S. Gross, "A Long Overdue Farewell: The Purported Jewish Origins of Syriac Christianity" (p. 121-144) ;

8 G. Herman, "Exilarch and Catholicos: A Paradigm for the Commonalities of the Jewish and Christian Experience under the Sasanians" (p. 145-154);

R. Kalmin, “Contextualizing Late Antique Rabbinic Narratives" (p. 155-170);

10 N. Koltun-Fromm, "Syriac Fathers on Jerusalem" (p. 171-186) ;

11 S. Minov, "Staring Down a Laundress: Reading Hagiographic Literature from SyriaMesopotamia Alongside Rabbinic Writings" (p. 187-206);

"Versions and Perversions of Genesis: Jacob of Edessa, Saadia Gaon, and the Falsification of Biblical History" (p. 207-230);

O. Münz-Manor, "Hebrew and Syriac Liturgical Poetry: A Comparative Outlook" (p. 231-254);

14 J. L. Rubenstein, "Syriac Christian Sources and the Babylonian Talmud" (p. 255-280);

15 C. Stadel, "Judaeo-Syriac: Syriac Texts in Jewish Square Scrip" (p. 281-290);

16 J. E. Walters, “Anti-Jewish Rhetoric and Christian Identity in Aphrahaț's Demonstrations" (p. 291-320);

17 R. D. Young, "The Anonymous Mēmrā on the Maccabees: Jewish Pseudepigraphon or Late-Ancient Festal Poem?" (p. 321-336).

Une série d'indices très détaillés clôt le volume (p. 339-350) : 1. Ancien Testament / Bible hébraïque ; 2 . Littérature apocryphe et pseudépigraphe ; 3 . Nouveau Testament; 4. Manuscrits de la mer Morte ; 5 . Auteurs juifs hellénistiques ; 6 . Auteurs et textes juifs rabbiniques et médiévaux; 7. Auteurs et textes chrétiens anciens et médiévaux; 8. Auteurs et textes musulmans; 9. Auteurs et textes classiques (grec et latin); 10. Sujets. Il marque un jalon important dans le domaine grâce à la méthodologie adoptée en recherches croisées. 


\section{AUTEURS}

FLORENCE JULLIEN

CNRS, CeRMI, Paris 